\title{
THE RELATION OF OVERPROTECTIVE PARENTING WITH EARLY CHILDHOOD SPEECH ABILITY IN THE DIGITAL ERA

\author{
Oleh:
}

\author{
An-An Andari ${ }^{1}$, Diden Rosenda ${ }^{2}$, Asep Supriadi AA $^{3}$
}

Universitas Pendidikan Indonesia, UIN Sunan Gunung Djati

\begin{abstract}
The progress of the time is very influential to the world civilization. In the era of globalization, all forms of social interaction are replaced with all-digital equipment. It is characterized by the popularity of sophisticated electronic equipment ranging from television, cell phone, internet and other communication tools. The progress of the time affects the nurture that given by parents to children. Overprotective parenting is an excessive nurture of parent to their children. By reason of fear, the parents do not give a freedom to the children to do their preferred activity, beside that, there are still many parents who provide communication tools that are not appropriate with the age, needs and development of their children. This research aims to determine whether there is a relationship between an overprotective parenting to the speech ability of early childhood children. The study was conducted in Laboratory Kindergarten of UPI Cibiru Bandung regency, with 24 respondents. The instruments which are developed in this study are the instrument of overprotective parenting and instrument on children's speech ability. The data collection was done by questionnaire. The research uses correlational descriptive methods, and the data analysis used a correlation test. The results showed a correlation of $(0,0383<0.05)$, then Ho is rejected, it means that there is a significant relationship between overprotective parenting style with the children's speech ability in early childhood in the Laboratory Kindergarten of UPI Cibiru, Bandung regency
\end{abstract}

Keyword: Parenting, overprotective, speech ability

\begin{abstract}
Abstrak: Kemajuan jaman sangat berpengaruh terhadap peradaban dunia, di era globalisasi ini segala bentuk interaksi sosial banyak yang tergantikan dengan alat-alat serba digital, hal ini ditandai dengan maraknya alat elektronik yang canggih dari mulai televisi, hanphone, internet dan alat komunikasi lainnya. Kemajuan jaman juga berpengaruh terhadap pola asuh yang diberikan orang tua terhadap anak, masih banyak orang tua yang memberikan alat komunikasi yang tidak sesuai dengan kebutuhan dan usia perkembangan anak. Penelitian ini bertujuan untuk mengetahui apakah terdapat hubungan antara pola asuh over protektif terhadap kemampuan bicara anak usia dini. Penelitian dilakukan di Taman kanak-kanak Laboratorium UPI Cibiru Kabupaten Bandung dengan responden sejumlah 24 orangtua. Instrumen yang dikembangkan dalam penelitian ini yaitu instrumen tentang pola asuh dan instrumen tentang kemampuan berbicara anak usia dini. Pengumpulan data dilakukan dengan kuisioner. Penelitian ini menggunakan metoda deskriptif korelasional, analisis data menggunakan uji korelasi. Hasil penelitian menunjukkan terdapat hubungan yang positif, kuat dan signifikan dengan korelasi sebesar $(0,0383<0,05)$ maka Ho ditolak, artinya bahwa ada hubungan signifikan antara pola asuh over protektif dengan kemampuan berbicara anak usia dini di Taman Kanak-kanak Laboratorium UPI Cibiru Kabupaten Bandung
\end{abstract}

Kata Kunci: Pola Asuh, Over Protektif, kemampuan Berbicara

\footnotetext{
'Universitas Pendidikan Indanesia, Email: ananandari@ upi.edu

2 UIN Sunan Gunung Djati

3 UIN Sunan Gunung Djati
} 
The first and principal education for children is the education that given by parents. The parents should be wise in giving nurture and education to their children. Appropriate parenting has a significant role in the children's learning process. The experience of nurturing and educating children are usually gained from generation generation. Parents who receive a democratic parenting pattern from their parents will adopt a democratic parenting pattern also to their children, as well as the parents who have authoritarian, overprotective and permissive parenting will undoubtedly generate that kind of parenting to the next generation. There are also parents who give freedom to children but still provide control, and there are parents who excessively protect their children against harassment and both physical and psychological danger, until the children are always dependent on parents, these kinds of parenting are called overprotective. Based on the reason so as children are not harmed, and because children can not think logically, then the parents choose to keep their children at home by providing facilities such as television and gadgets and all of digital tools. The children are only accompanied by the shows and the game on TV, mobile phone or gadget.

With the technology development, a sophisticated electronic device becomes a lifestyle called digital lifestyle. This is an effect of the technology utilization itself. It is man who create the technology, even until today there are many experts who are competing to create sophisticated technology. They are trying to make the consumers satisfied. The sophistication of this technology is also closely related to the market which in turn makes many people become more consumptive in technology. In this global era, any social interaction tools use sophisticated tools, even many people compete to always use the latest and most advanced tools, therefore this phenomenon is called a digital lifestyle, a very modern style equipped with the latest information technology. The progression in technology is improving the efficiency of life, but it should be balanced with the behavior of the user. The currently happen is that parents provide mobile phones or gadgets since the children are still in the early age when they did not need it yet.

Parents who have overprotective parenting prefer to give children many toys at home rather than allowing them to play freely outside. The role of parents is needed to facilitate the children development in this modern era, where everything uses the high technology. This effort must be accompanied by the wise and appropriate parenting that correspond to the children's development age.

\section{LITERATURE REVIEW}

Parents' parenting has the enormous influence in determining the type of the children's personal in the future. Parents must be wise and focus on instilling the good values of life and norms to the child through appropriate, good and true parenting. Parents are the first environment for children who have a crucial role in the development of children, especially children's speech development. Good parenting for the formation of the children's personality is parenting which prioritize the interests of the children, with the emphasis on the parents' supervision and control

The parents who realize their role and function, will be able to position themselves better and apply the parenting and coaching in more appropriate way (Mardiya, 2010). What happens this day is there are a lot of parents who apply the parenting they get from their parents before, this is accordance with the statement that most of parents learn parenting practices from their own parents (Santrock, 2011).

In addition to the role of parents, the role of education also provide opportunities for children to be independent, the family are still the pillar 
and the first in shaping the children to be independent (Jayantini, et.al 2014, p. 2). Kartono (1996) suggested that parents always give freedom to do activity but still give direction. The children will be free to do the learning activity by themselves yet will be responsible for the result that received later, be brave, have a high confidence, not dependent on their parents and live their life with fun.

If parents applied the democratic parenting the children's growth will be better. In treating their children, of course parents do not behave recklessly. They have their own way with the hope their children develop as expected. The behavior of parents to children plays a big role in the development of children in the future, because childhood is a critical period that become the basis for success to carry out the task of further development. The first time of children's interaction is with the parent, so that the behavior of parents to children become the determinant for the development of children, both physical and psychological development.

The mindset of parents who still apply the nurture from generation to generation must to be changed. The average ancient parents were using authoritarian parenting, and the parenting that is widely applied today is overprotective parenting. They reasoned because of excessive anxiety, then they protect their children by facilitating all social interaction with alldigital electronic tools to replace the outside environment.

Digital era is a term that is used in the emergence of digital, internet network, especially computer information technology. Digital lifestyle is something that is related to the even distribution of human desire, where technology is used as a means to achieve the maximum activity. It further illustrates the fulfillment of human productivity. (Michael Surya;2016)

According to Yusuf cited from

Nurela, (2012) the aspect of overprotective parents' behavior is an excessive contact to children, care or assistance to children continuously, overseeing their activities in excess and solve their problem. By applying overprotective parenting, the digital era becomes the strong reason for parents to protect children from their freedom of play with other children so that their social interaction is replaced with all-digital communication tools.

Children rarely communicate with other friends, they do not make direct contact and only focus to the toys or games on their mobile phone or gadget.

Agree with the above statement, according to Sugianto (Nurela: 2012) said that to determine whether the children have a speech disorder or not, it should be considered the stages of children's speech development. The children are said to have speech impaired or cannot speak, can be seen from the stage of speech and language development experienced by children aged 4 years, namely: 1). understanding 1500-2000 vocabulary, 2). Understand the word if, because, or who, $3)$. use 4-5 words in one sentence, 4). Start to use language in a good structure, 5). Give a clearer articulation, 6) are able to follow the 2-3 steps command. Stages of speech development of children in age 5: 1) understanding 2500-2800 vocabulary, $2)$. Define the objects by function, 3 ) cannot distinguish between the concept of yesterday, past or tomorrow, 4) able to exchange information, can answer the phone and connect the story, 5) use 5-6 words in one sentence

By knowing the stages of speech development of children, the parents are able to detect whether their children have speech impaired or not, and parents would be wise to understand if they provide a communication tools or digital plaything for children which are not appropriate in the children development age. 


\section{RESEARCH METHODOLOGY}

The research design that is used in this study is correlational that examines the relationship between overprotective parenting with the children speech ability, where researchers can search, describe a relation, and test based on the theory. It is in accordance with the opinion that the correlational research aims to reveal the correlative relation inter- variable (Alimul, 2012).

The population in this study are all parents of children aged 4 to 5 years in the Laboratory Kindergarten of UPI Cibiru as many as 24 people. The independent variable data namely the overprotective parenting, for the questionnaire of parenting style as many as 12 questions, from the questionnaire then the answer are tabulated or grouped based on respondents answer. The results of respondents who have been given a score, are tabulated, summed and compared with the highest score and then multiplied.

\section{RESEARCH RESULT AND DISCUSSION}

Based on the results of research in the Laboratory Kindergarten of UPI Cibiru Bandung regency, of 24 respondents almost halved apply the high overprotective parenting, as many as 18 respondents $(77.78 \%)$, a small part of respondents as much 6 people $(22: 22 \%)$ classified as a low overprotective parenting. The result of this research, showed that almost the majority of parents apply the high overprotective parenting. Overprotective parenting of parents affected by the surrounding environment and the anxiety from parents. In accordance with the opinion of Kartono in Dinna (2014) that excessive fear of parents of the dangers that may threaten the child.

From the interviews and questionnaires, it was found that almost $80 \%$ of parents in Laboratory Kindergarten of UPI Cibiru apply overprotective parenting pattern, this is because parents feel worried about the society in the free environment, then they finally apply overprotective parenting pattern. The main reason of why parents forbid their children to play with their friends outside is because children use rude language, inappropriate and disrespectful, thus parents provide games on mobile phones, and provide cable television etc

Parents do not realize that the implement of overprotective parenting to children impact their social skills, it is proved from the less of social interaction of the children, the speech becomes stiff like a language that children find on television. There are many children who speak that mimic the accent of "upin and ipin", follow the character of Dora and even follow the language style on television ads.

\section{CONCLUSIONS}

Overprotective parenting in Laboratory Kindergarten of UPI Cibiru Bandung regency, in average apply the high overprotective parenting as much $(77,2$ $8 \%$ ). Of the 24 respondents show the low of children's speech ability as much $(22.22 \%)$. The relation of overprotective parenting with the early childhood speech in Laboratory Kindergarten of UPI Cibiru Bandung regency, as much 0.881>0.05. That means $\mathrm{H} 0$ is accepted and in other words there is no significant relationship between overprotective parenting with the development of early childhood in Laboratory Kindergarten of UPI Cibiru Bandung regency.

\section{REFERENCES}

Alimul, Aziz A. (2012). Riset keperawatan dan aplikasi teknik penulisan Ilmiah. Jakarta: Salemba Medika.

Kartono, K. 1996. Patologi Sosial II (Kenakalan Remaja). Jakarta: Raja Grafindo Persada.

Jayantini, N. M. S., Made Sulastri, M. P., \& Sedanayasa, G. (2014). Hubungan Pola Asuh Orang Tua Terhadap 
Kemandirian Belajar Siswa Kelas XI SMA Negeri 1 Sukasada Tahun Pelajaran 2013/2014. Jurnal Ilmiah Bimbingan Konseling Undiksha, 2(1).

Mardiya. (2010). Memahami Perkembangan Nilai Moral Keagamaan pada anak.

Michael Surya A R, (2016). Pengaruh era Digital terhadap kehidupan kita

Nurela. (2012). Hubungan antara perilaku over protective orang tua Dengan penyesuaian diri remaja. IAIN: Cirebon.

Santrock, John W. (2011). Masa perkembangan anak. Jakarta: Salemba Humanika

Sri Jayantini dkk. (2014). hubungan pola asuh orang tua terhadap kemandirian belajar siswa kelas xi sma. e-journal Undiksa Jurusan Bimbingan Konseling. volume: 2:2. 